MISS ZHUO SHEN (Orcid ID : 0000-0002-6839-0418)

DR. DAODE JI (Orcid ID : 0000-0002-4878-9640)

DR. XIAOFENG LIN (Orcid ID : 0000-0001-7886-7198)

Article type : Original Article

LIANG ET AL. - Morphology and Phylogeny of Vorticella Species

\title{
Morphology and Phylogeny of Four New Vorticella Species (Ciliophora: Peritrichia) from Coastal Waters of Southern China
}

Ziyao Liang ${ }^{\mathrm{a}, \#}$, Zhuo Shen $^{\mathrm{a}, \mathrm{b}, \#, \text { Yong Zhang }}{ }^{\mathrm{a}}$, Daode Ji ${ }^{\mathrm{c}}$, Jiqiu Li ${ }^{\mathrm{a}}$, Alan Warren $^{\mathrm{d}}$, Xiaofeng Lin ${ }^{\mathrm{a},{ }^{*}}$

a Laboratory of Protozoology, Guangzhou Key Laboratory of Subtropical Biodiversity and Biomonitoring, School of Life Science, South China Normal University, Guangzhou 510631, China

${ }^{b}$ Microbial Ecology and Matter Cycle Group, School of Marine Sciences, Sun Yat-sen University, Zhuhai, 519082, China

${ }^{\mathrm{c} S}$ School of Ocean, Yantai University, Yantai 264005, China

${ }^{\mathrm{d}}$ Department of Life Sciences, Natural History Museum, Cromwell Rd., London SW7 5BD, UK.

\# These authors contributed equally to this work.

* Correspondence

X. Lin, Laboratory of Protozoa, South China Normal University, Guangzhou 510631, China

E-mail: xlin@scnu.edu.cn; Telphone/Fax: +86-20-8521 0644

\section{ABSTRACT}

Four new species of Vorticella, V. parachiangi sp. n., V. scapiformis sp. n., V. sphaeroidalis sp. n., and $V$. paralima sp. $\mathrm{n}$., were isolated from coastal brackish waters of southern China. Their morphology, infraciliature, and silverline system were investigated based on observations of specimens both in vivo and following silver staining. Vorticella parachiangi sp. $\mathrm{n}$. is distinguished by: a J-shaped macronucleus; a single dorsally located contractile vacuole; a two-rowed infundibular polykinetid 3, in which row 1 is shorter than row 2; 21-31 silverlines between peristome and aboral trochal band, 6-11 between aboral trochal band and scopula. Vorticella scapiformis sp. $\mathrm{n}$. is characterized by its

This article has been accepted for publication and undergone full peer review but has not been through the copyediting, typesetting, pagination and proofreading process, which may lead to differences between this version and the Version of Record. Please cite this article as doi: 10.1111/jeu.12668

This article is protected by copyright. All rights reserved. 
conspicuously thin and irregularly edged peristomial lip; a J-shaped macronucleus; a single, ventrally located contractile vacuole; row 1 of the infundibular polykinetid 3 proximally shortened; $18-25$ silverlines between peristome and aboral trochal band, 8-12 between aboral trochal band and scopula. Vorticella sphaeroidalis sp. $\mathrm{n}$. can be identified by its small, sub-spherical zooid; a C-shaped macronucleus; a ventrally located contractile vacuole; an aboral trochal band adjacent to the scopula; $16-18$ silverlines between persitome and aboral trochal band, two between aboral trochal band and scopula. Vorticella paralima sp. $\mathrm{n}$. can be identified by its ovoidal zooid; a J-shaped macronucleus; a dorsally positioned contractile vacuole; rows 1 and 2 of the infundibular polykinetid 3 proximally shortened; $26-35$ silverlines from peristome to aboral trochal band, and 7-13 from aboral trochal band to scopula. The SSU rDNA genes of these four species were sequenced and their phylogeny was analyzed.

Keywords: Biodiversity; brackish water; mangrove wetland; Vorticellida; taxonomy.

THE peritrich order Vorticellida which comprises over 100 genera, is a large, distinctive assemblage of ciliates that are commonly found in a wide variety of marine, freshwater, and terrestrial habitats (Foissner et al. 2010; Li et al. 2015; Lynn 2008; Shen et al. 2017; Sun et al. 2015). The sessilids comprise two major sub-clades, i.e., the refined sub-orders Vorticellina de Fromentel. 1875 and Operculariina Jankowski, 1980, as recognised by Jankowski (2007). Based on analyses of their molecular phylogeny, Utz et al. (2010) suggested that the two sessilid sub-clades should be assigned to the rank of order, i.e., Vorticellida and Operculariida. Discussion of peritrich taxonomy above the rank of family is outside the scope of this paper. Vorticella Linnaeus, 1767 was the first reported genus of peritrichs. The generic definition was refined by Ehrenberg (1838), who limited it to the solitary Vorticellidae with an unbranched, spirally contractile stalk. Subsequently, Vorticella became the largest genus of sessile peritrichs with over 300 species having been described in the 250 years since it was created. Noland and Finley (1931) published the first comprehensive revision of the genus, listing 220 species or named varieties that had been assigned to the genus by 1930, and reduced its membership to 95 species following the elimination of many that obviously belonged to other peritrich genera, to other ciliate taxa, or to animal phyla (e.g., rotifers, cnidarians, crinoids). An additional 113 species, varieties, or forms of Vorticella were described in the period between Noland and Finley's paper and publication of the next major revision of the genus by Warren (1986) who excluded over 100 dubious species, reducing the total membership of the genus to 86 species. Many new species of Vorticella have since been described, raising the total to more than 100 again (e.g., Song 1997; Sun et al. 2006, 2009, 2017).

The specialized morphology of Vorticella reflects its sessile, suspension-feeding lifestyle. The cell body, or zooid, is usually shaped like an inverted bell but may be cylindroid, conical or sub-spherical. The exposed part of the oral region is the peristome, a generally flattened surface with a thickened border or lip and a raised epistomial disc in the center. Two bands of cilia, the haplokinety and polykinety, run counterclockwise around the peristome and beat to create a vortex that carries suspended particles into the oral opening or infundibulum. The shape and size of the zooid, width of

This article is protected by copyright. All rights reserved. 
the peristome, height and contour of the epistomial disc and thickness of the peristomial lip have been used as taxonomic characters. Species identification of Vorticella is, however, frequently very difficult because of its variable zooid shape and size and its highly contractile nature resulting in the creation of numerous species and varieties of doubtful taxonomic validity (Itabashi et al. 2002; Noland and Finley 1931; Warren 1986).

In the last 50 years, silver staining methods have been used to reveal additional characters for species circumscription and identification. These include the transverse pellicular ridges that encircle the zooid and can be visualized either as as silverlines by staining with silver nitrate or directly by scanning electron microscopy, and the structure of the infundibular polykineties within the infundibulum, which can be revealed by staining with protargol. These characters are now routinely used in the determination of species (Sun et al. 2006, 2017). More recently, gene sequence information has also been included in species descriptions and redescriptions (Ji et al. 2015; Sun et al. 2012). Phylogenetic studies based on gene sequence data derived from carefully identified species have shown that Vorticella is a paraphyletic group (Gao et al. 2016; Sun et al. 2012, 2013).

In the present study, four new solitary vorticellids were discovered during a survey of ciliate diversity in coastal waters of southern China. Detailed investigations of the specimens, both in vivo and following silver staining (protargol and silver nitrate), and analysis of their small subunit (SSU) rDNA gene sequences revealed them to be new members of the genus Vorticella.

\section{MATERIALS AND METHODS}

\section{Sample collection}

Vorticella parachiangi sp. $\mathrm{n}$. was collected on $14^{\text {th }}$ March 2010 from a mangrove wetland on Techeng Island $\left(21^{\circ} 16^{\prime} \mathrm{N} ; 110^{\circ} 44^{\prime} \mathrm{E}\right)$ in Zhanjiang, Guangdong Province, China, at a water temperature of 25 ${ }^{\circ} \mathrm{C}$, a salinity of $25 \%$, and a $\mathrm{pH}$ of about 7 .

Vorticella scapiformis sp. n. was collected on $21^{\text {st }}$ March 2010 from a sewage discharge outlet on Donghai Island ( $\left.21^{\circ} 02^{\prime} \mathrm{N} ; 110^{\circ} 34^{\prime} \mathrm{E}\right)$ in Zhanjiang, Guangdong Province, China, at a water temperature of $25^{\circ} \mathrm{C}$, a salinity of $12 \%$, and a pH of about 9 .

Vorticella sphaeroidalis sp. $\mathrm{n}$. was collected on $5^{\text {th }}$ May 2011from a small ditch near the coast $\left(23^{\circ} 38^{\prime} \mathrm{N} ; 116^{\circ} 68^{\prime} \mathrm{E}\right)$ of Shantou, Guangdong Province, China, at a water temperature of $23^{\circ} \mathrm{C}$, a salinity of $5 \%$, and a pH of about 7.

Vorticella paralima sp. $\mathrm{n}$. was collected on $11^{\text {th }}$ October 2009 from Gaoqiao mangrove wetland $\left(21^{\circ} 53^{\prime} \mathrm{N} ; 110^{\circ} 28^{\prime} \mathrm{E}\right)$ in Zhanjiang, Guangdong Province, China, at a water temperature of $23^{\circ} \mathrm{C}$, a salinity of $23 \%$, and a pH of about 7.8 .

\section{Morphological studies}

Ciliates were observed in vivo using bright field and differential interference contrast microscopy (Nikon $80 \mathrm{i}$, Japan). The infraciliature and silverline system were revealed by the protargol method following Wilbert (1975) and the Chatton-Lwoff silver nitrate-stain method following Song and Wilbert (1995), respectively. Counts and measurements of stained specimens were performed at

This article is protected by copyright. All rights reserved. 
$1,000 \times$ magnification. Drawings of stained specimens were conducted by hand with the help of a camera lucida at 1,000x magnification. Classification and terminology are according to Lynn (2008).

\section{SSU rDNA gene sequencing and phylogenetic analysis}

Genomic DNA was extracted, using the RED Extract-N-Amp Tissue PCR Kit. The SSU rDNA sequence was amplified by PCR, using the following primers: EukA (5'-AACCTGGTTGATCCTGCCAGT-3'), EukB (5'-TGATCCTTCTGCAGGTTCACCTAC-3') (Medlin et al. 1988). Cycling parameters were as follows: one cycle for initial denaturation $\left(94^{\circ} \mathrm{C}\right.$ for $5 \mathrm{~min}$ ); 35 cycles for amplification $\left(94^{\circ} \mathrm{C}\right.$ for $1 \mathrm{~min} ; 56{ }^{\circ} \mathrm{C}$ for 2 min; $72{ }^{\circ} \mathrm{C}$ for $2 \mathrm{~min}$ ) and one cycle for the final extension $\left(72{ }^{\circ} \mathrm{C}\right.$ for $10 \mathrm{~min}$ ).

Phylogenetic trees were constructed by two methods: Bayesian inference (BI) and maximum likelihood (ML). Fifty-six taxa were used for phylogenetic analyses, including the four that were newly sequenced and 52 previously sequenced obtained from the NCBI GenBank database. The SSU rDNA of three Vorticella species sequenced by Sun et al. (2013), namely, V. chlorostigma, V. striata and $V$. natans, were removed from the alignment after preliminary analysis because of their short lengths. The hymenostomes Tetrahymena bergeri and $T$. corlissi were selected as outgroup taxa. Sequences were aligned with the ClustalW Multiple alignment in BioEdit 7.2.5 (Hall 1999) and then refined by removing ambiguous gaps at both termini of the alignment and in the highly variable $\mathrm{V} 4$ and $\mathrm{V} 9$ regions. The length of the final alignment was $1,616 \mathrm{bp}$.

The tree topologies were inferred, using the best-fit model GTR $+\mathrm{I}+\mathrm{G}$ selected by AIC criterion in MrModeltest 2.2 (Nylander 2004). A $50 \%$ majority-rule Bayesian inference tree was constructed with MrBayes 3.1.2 (Ronquist and Huelsenbeck 2003). The chain length for the analysis was $1,000,000$ generations with trees sampled every 100 generations; the first $25 \%$ of trees were discarded as burn-in (Li et al. 2015). The Maximum likelihood trees inferred from the sequences were constructed with the PhyML 3.0 program (Guindon et al. 2005) with a parametric bootstrap base frequency of 1,000 .

ZooBank registration: ZooBank registration number of the present work (see Recommendation $8 \mathrm{~A}$ of ICZN 2012): urn:Isid:zoobank.org:pub: C1F52FCF-46AB-4444-900E-1CD9B58FA00A.

\section{RESULTS}

\section{Description of Vorticella parachiangi sp. $\mathbf{n}$.}

Zooid inverted campanulate when expanded, size 50-65 $\mu \mathrm{m} \times 55-70 \mu \mathrm{m}$ in vivo, ratio of length to width about 1:1, maximum width at peristome. Peristomial lip thin, ca. $4 \mu \mathrm{m}$ thick. Epistomial disc slightly elevated above peristome (Fig. 1A, C, 2A, C). Length of oral cilia about $12 \mu \mathrm{m}$. Pellicle occasionally slightly folded on ventral and dorsal sides (Fig. 1C, 2D). Transverse pellicular striations visible at $1000 \times$ magnification (Fig. 2E, arrows). Telotroch not observed.

Cytoplasm semi-transparent, slightly gray, usually containing a few food vacuoles about 10-15 $\mu \mathrm{m}$ in diameter (Fig. 1A, C). Contractile vacuole near dorsal wall of infundibulum, approximately $10 \mu \mathrm{m}$ in diameter when fully expanded (Fig. 1A, 2D). Macronucleus J-shaped, apical portion horizontally oriented around infundibulum, hook-shaped posterior portion extends almost longitudinally to level of aboral trochal band. Micronucleus not observed.

Stalk up to $350 \mu \mathrm{m}$ long and $4 \mu \mathrm{m}$ in diameter, surface smooth without attached bacteria. Stalk spasmoneme about $2 \mu \mathrm{m}$ in diameter, with a string of light gray thecoplasmic granules (ca. $0.5 \mu \mathrm{m}$ in diameter) sparsely distributed along its length (Fig. 2F).

This article is protected by copyright. All rights reserved. 
Haplokinety and polykinety describe about $1 \frac{1}{4}$ turns around peristome and continue into infundibulum where they separate and make a further turn. Polykinety transforms into three infundibular polykineties (P1-3) at lower half of infundibulum. P1 and P2 are composed of three distinct rows of kinetosomes, P3 is two-rowed (Fig. 1E, F). Row 1 of P3, i.e. the one nearest to P2, is only half length of row 2 and terminates together with $\mathrm{P} 2$, while row 2 of $\mathrm{P} 3$ extends to the proximal end of P1 (Fig. 1F, 2H). Germinal kinety lies in distal half of infundibulum, parallel to haplokinety. Epistomial membrane located at entrance of infundibulum (Fig. 1F, 2H). Aboral trochal band dikinetidal, encircles zooid at $80 \%$ distance from peristome to scopula (Fig. 1E, 2G). Silverline system consists of 21-31 silverlines between peristome and aboral trochal band and 6-11 between aboral trochal band and scopula; with sparsely distributed pellicular pores (Fig. 1D, 2I; Table 1).

\section{Description of Vorticella scapiformis sp. $\mathbf{n}$.}

Zooid elongate obconical in expanded state, size 40-50 $\mu \mathrm{m} \times 40-55 \mu \mathrm{m}$ in vivo, maximum width at peristome, with constriction posterior to peristomial lip, which is approximately $2 \mu \mathrm{m}$ thick. Peristome with irregular protuberances on rim. Epistomial disc slightly convex (Fig. 3A, C, 4A, B). Length of oral cilia about $10 \mu \mathrm{m}$. Telotroch not observed.

Cytoplasm semi-transparent and slightly grayish, usually containing a few to several ellipsoidal or spherical granules (3-6 $\mu \mathrm{m}$ in diameter) and food vacuoles (8-10 $\mu \mathrm{m}$ in diameter) (Fig. 3A, 4A, D). Contractile vacuole located near ventral wall of infundibulum at about $25 \%$ of body length, approximately $12 \mu \mathrm{m}$ in diameter when fully expanded (Fig. 3A, B, 4C). Macronucleus J-shaped, apical portion horizontally oriented around infundibulum, hook-shaped posterior portion extends almost longitudinally to level of aboral trochal band (Fig. 3E, 4G). Micronucleus not observed. Pelliclular striations closely spaced, visible at 1,000× magnification (Fig. 4E).

Stalk 500-600 $\mu \mathrm{m}$ in length and $6 \mu \mathrm{m}$ in diameter with smooth surface. Stalk spasmoneme about 2 $\mu \mathrm{m}$ in diameter with dark gray thecoplasmic granules (ca. $0.5 \mu \mathrm{m}$ in diameter) sparsely distributed at periphery (Fig. 3D, 4F). Haplokinety and polykinety make approximately $1 \frac{114}{4}$ turns around peristome before entering infundibulum where they separate and make a further half-turn. Polykinety transforms into three infundibular polykineties (P1-3) at lower half of infundibulum. P1-3 composed of three kinetosome rows each. P1 converges with P3 in proximal portion of infundibulum and terminates at same level as the latter. Row 1 of $\mathrm{P} 3$ shortened proximally and terminates at curvature of P1. P2 terminates near the curvature of P1, just above row 1 of P3. Germinal kinety lies in distal portion of infundibulum, parallel to haplokinety (Fig. 3E, F, 4H). Epistomial membrane located near entrance of infundibulum. Aboral trochal band dikinetidal, encircles zooid at $85 \%$ distance from peristome to scopula (Fig. 3E). Silverline system consists of 18-25 silverlines between peristome and aboral trochal band and 8-12 between aboral trochal band and scopula (Fig. 4I; Table 1).

\section{Description of Vorticella sphaeroidalis sp. $\mathbf{n}$.}

Zooid almost globular, size 20-30 $\mu \mathrm{m} \times 15-25 \mu \mathrm{m}$ in vivo, maximum width at mid-body. Peristome approximately $15 \mu \mathrm{m}$ across. Peristomial lip moderately thick. Epistomial disc elevated high above persitome (Fig. 5A, B, 6A, B). Length of oral cilia about $7 \mu \mathrm{m}$. Pellicular striations and several grayish granules visible on zooid surface at $400 \times$ magnification (Fig. 5E, 6E, G). Telotroch not observed.

Cytoplasm semi-transparent, slightly grayish and containing a few food vacuoles, 3-5 $\mu \mathrm{m}$ in diameter (Fig. 6D). Contractile vacuole located near ventral wall of infundibulum, approximately 6 $\mu \mathrm{m}$ in diameter when fully expanded (Fig. 5A, B, 6C). Macronucleus C-shaped, transversely oriented, surrounding opening of infundibulum (Fig. 5D, 6D, H). Micronucleus not observed.

This article is protected by copyright. All rights reserved. 
Stalk approximately 40-50 $\mu \mathrm{m}$ long, $2 \mu \mathrm{m}$ across, surface smooth occasionally with some attached bacteria and algae. Spasmoneme about $1 \mu \mathrm{m}$ in diameter, with several slightly grayish thecoplasmic granules (ca. $0.3 \mu \mathrm{m}$ in diameter) distributed in periphery.

Haplokinety and polykinety make approximately $1 \frac{1}{4}$ turns around peristome and extend into infundibulum where they separate and make a further turn. Polykinety transforms into three infundibular polykineties (P1-3) at lower half of infundibulum. P1 and P2 are composed of three distinct rows of kinetostomes. Arrangement of $\mathrm{P} 3$ unclear due to limited number of specimens and improper specimen orientation for observation. P3 very likely two-rowed (Fig. 5C, D). Aboral trochal band dikinetidal, encircles zooid at $88 \%$ distance from peristome to scopula (Fig. 5D, 6G).

Silverline system consists of 16-18 silverlines between peristome and aboral trochal band and two between aboral trochal band and scopula; with sparsely distributed pellicular pores (Fig. 5E, 6J, K; Table 1).

\section{Description of Vorticella paralima sp. $\mathbf{n}$.}

Zooid obovoid, with truncated oral end and narrowed aboral end in expanded state, size $35-50 \mu \mathrm{m} \times$ 20-30 $\mu \mathrm{m}$ in vivo. Cell proper usually widest at mid-body, with constriction posterior to peristomial lip (Fig. 7A, B, 8A, B). Peristomial lip everted and thin, approximately $3 \mu \mathrm{m}$ thick. Epistomial disc elevated about $4 \mu \mathrm{m}$ above peristome. Oral cilia about $12 \mu \mathrm{m}$ long (Fig. 7A, B, 8A, C). Pellicular striations observable at 1,000 x magnification (Fig. 8D, E).

Cytoplasm semi-transparent and slightly grayish, usually containing a few to several food vacuoles 3-5 $\mu \mathrm{m}$ in diameter. Contractile vacuole located at dorsal wall of infundibulum in anterior fourth of zooid, about $7 \mu \mathrm{m}$ in diameter when fully expanded (Fig. 8A, C). Macronucleus J-shaped, apical portion horizontally oriented around infundibulum, hook-shaped posterior portion terminates slightly below level of aboral trochal band (Fig. 8F). Micronucleus not observed.

Stalk approximately 80-120 $\mu \mathrm{m}$ long and $4 \mu \mathrm{m}$ in diameter, surface smooth with a few attached bacteria and algae. Spasmoneme about $2 \mu \mathrm{m}$ in diameter; thecoplasmic granules not observed (Fig. 7B).

Haplokinety and polykinety make approximately $1 \frac{1}{2}$ turns around peristome and extend into infundibulum where they separate and make another turn. Polykinety transforms into three infundibular polykineties (P1-3) at lower half of infundibulum. P1-3 three-rowed. P1 and P3 converge at curvature of the latter. Row 3 of $\mathrm{P} 3$ extends to the end of infundibulum where it terminates near the end of P1. Rows 1 and 2 of P3 are half the length of row 3, terminating together with P2 (Fig. 7D, $8 G)$. Germinal kinety lies in distal portion of infundibulum parallel to haplokinety. Epistomial membrane near entrance of infundibulum (Fig. 7E). Aboral trochal band dikinetid, encircles zooid at $75 \%$ distance from peristome to scopula (Fig. 7D, 8F).

Silverline system consists of 26-35 silverlines from peristome to aboral trochal band and 7-13 from aboral trochal band to scopula; with numerous irregularly distributed pellicular pores (Fig. 7F, 8H, I; Table 1).

\section{Analyses of SSU rDNA sequence}

The four new SSU rDNA sequences have been deposited in the GenBank database with length and GC content as follows: Vorticella parachiangi sp. n., 1,729 bp, 44.07\%; V. scapiformis sp. n., 1,727 bp, 43.66\%; V. sphaeroidalis sp. n., 1,742 bp, 43.51\%; V. paralima sp. n. 1,651 bp, 43.50\%.

Phylogenetic trees constructed with $\mathrm{ML}$ and $\mathrm{BI}$ analyses had almost identical topologies, therefore only the ML tree is shown here (Fig. 9). In all phylogenetic analyses, the three new species clustered

This article is protected by copyright. All rights reserved. 
with species of Vorticella and Pseudovorticella within the family Vorticellidae. Within the Vorticella-Pseudovorticella subclade, V. parachiangi sp. $\mathrm{n}$. is sister group to V. scapiformis sp. $\mathrm{n}$. with maximal support (100\% ML, $1.00 \mathrm{BI})$, V. sphaeroidalis $\mathrm{sp} . \mathrm{n}$. and Vorticellides astyliformis cluster together with high support ( $95 \% \mathrm{ML}, 1.00 \mathrm{BI}$ ) and are sister to the Vorticellides aquadulcis-complex with differential support ( $99 \% \mathrm{ML}, 0.53 \mathrm{BI})$. Vorticella paralima sp. n. and Pseudovorticella species form a clade that is sister to the grouping of $V$. parachiangi sp. $\mathrm{n}$. and $V$. scapiformis $\mathrm{sp} . \mathrm{n}$.

\section{DISCUSSION}

Commonly accepted characters for species circumscription in Vorticella include zooid shape and size, number and location of contractile vacuoles, shape and position of the macronucleus, oral morphology (appearance of peristomial lip and epistomial disc), oral infraciliature (especially structure of P3), features of the silverline system, and habitat (Sun et al. 2006, 2017). The four new species could each be separated from their congeners and other similar taxa based on combinations of these characters.

\section{Comparison of Vorticella parachiangi sp. $\mathbf{n}$. with related species.}

Vorticella parachiangi sp. n. resembles $V$. chiangi Sun et al., 2017 in terms of its zooid shape. Nevertheless, it can be separated from the latter by the zooid size in vivo $(50-65 \mu \mathrm{m} \times 50-65 \mu \mathrm{m}$ vs. 35-50 $\mu \mathrm{m} \times 35-50 \mu \mathrm{m}$ ), the number of silverlines (21-31 vs. 33-37 between peristome and aboral ciliary wreath; 6-11 vs.10-14 between aboral ciliary wreath and scopula), and the structure of P3 (two-rowed vs. three-rowed) (Sun et al. 2017).

Another congener that closely resembles $V$. parachiangi sp. n. is V. fornicata (Dons, 1915), which has a similar zooid shape, but these species differ in the zooid size in vivo (50-65 $\mu \mathrm{m} \times 50-65 \mu \mathrm{m}$ vs. 24-32 $\mu \mathrm{m} \times 24-37 \mu \mathrm{m}$ ) and the shape of the macronucleus (J-shaped vs. horseshoe-shaped) (Song 1991).

Living cells of three Pseudovorticella species, namely, P. patellina Müller, 1776, P. marina (Greeff, 1870) Ji et al., 2009 and $P$. zhengae Ji et al., 2006, bear some resemblance to V. parachiangi sp. n. at low magnifications, although all three can be separated from the latter by having a reticulate (vs. transverse) silverline system. In addition, $P$. patellina has a much larger zooid in vivo than $V$. parachiangi sp. n. (55-110 $\mu \mathrm{m} \times 50-100 \mu \mathrm{m}$ vs. 50-65 $\mu \mathrm{m} \times 50-65 \mu \mathrm{m})$ and two (vs. one) contractile vacuoles (Song and Warren 2000). Vorticella parachiangi sp. $n$. can be separated from $P$. marina by zooid size in vivo (50-65 $\mu \mathrm{m} \times 50-65 \mu \mathrm{m}$ vs. $40-50 \mu \mathrm{m} \times 35-45 \mu \mathrm{m})$ and the structure of $\mathrm{P} 3$ (two-rowed vs. three-rowed) (Sun et al. 2009). Vorticella parachiangi sp. n. can be separated from $P$. zhengae by the number of transverse silverlines between the aboral trochal band and the scopula (6-11 vs. 11-14), and the structure of P3 (two-rowed vs. three-rowed) (Ji et al. 2006).

\section{Comparison of Vorticella scapiformis sp. $\mathbf{n}$. with congeners.}

Vorticella similis Stokes, 1887 and V. spuripicta Song, 1997 bear some resemblance to V. scapiformis sp. n. in terms of zooid shape, macronucleus shape, and habitat (Song 1997). Vorticella scapiformis sp. $n$. can be separated from $V$. similis by the shorter zooid (40-50 $\mu \mathrm{m}$ vs. 52-58 $\mu \mathrm{m})$, fewer transverse silverlines both between the peristome and the aboral trochal band and between the aboral trochal band and the scopula (18-25 and 8-12 vs. $75-80$ and 28-34) and in the position of the contractile vacuole (in the anterior $1 / 4$ of zooid vs. in mid-zooid) (Song 1997).

This article is protected by copyright. All rights reserved. 
Vorticella spuripicta differs from $V$. scapiformis sp. $\mathrm{n}$. in respect to the number of silverlines between the aboral trochal band and both the peristome and the scopula (35-39 and 11-15 vs. 18-25 and 8-12, respectively), and in having two (vs. one) contractile vacuoles (Song 1997).

\section{Comparison of Vorticella sphaeroidalis sp. $\mathbf{n}$. with congeners.}

Although the structure of P3 could not be clearly observed, $V$. sphaeroidalis sp. n. can be easily distinguished from its congeners by the combination of its small and globular zooid, and the location of the aboral trochal band close to the scopula. Three congeners, $V$. parapulchella Sun et al., 2006, V. pulchella Sommer, 1951, and $V$. sinica Sun et al., 2009, have to be compared with the new species. Vorticella sphaeroidalis sp. $\mathrm{n}$. resembles $V$. parapulchella in zooid size and number of silverlines. Nevertheless, the former differs from the latter in respect to the conspicuously more posterior position of its aboral trochal band, the globular (vs. barrel-shaped) zooid, and its brackish water (vs. marine) habitat (Sun et al. 2006).

Like V. sphaeroidalis sp. n., V. pulchella has widely spaced pellicular striations. However, the new species can be separated by its much shorter zooid size (20-30 $\mu \mathrm{m}$ vs. 40-46 $\mu \mathrm{m})$ and more posterior position of the aboral trochal band (Sommer 1951).

Vorticella sinica resembles $V$. sphaeroidalis sp. $\mathrm{n}$. in terms of zooid size and shape and widely spaced pellicular silverlines. However, $V$. sphaeroidalis sp. n. can be separated from the former by its single-layered (vs. double-layered) peristomial lip, very likely two-rowed (vs. three-rowed) P3, and the conspicuously more posterior position of its aboral trochal band (Sun et al. 2009).

\section{Comparison of Vorticella paralima sp. $\mathbf{n}$. with congeners.}

The congener that most closely resembles Vorticella paralima sp. n. is V. lima Kahl, 1933 which was transferred to the genus Pseudovorticella by Jankowski (1976), and transferred back to the genus Vorticella by Warren (1986). Vorticella paralima sp. n. differs from V. lima by: (1) its shorter zooid in vivo (35-50 $\mu \mathrm{m}$ vs. 60-70 $\mu \mathrm{m}$ ); (2) the shape of the macronucleus (very long, with a distinctly horizontal anterior portion and a recurved posterior portion vs. elongate, only slightly curved anteriorly and not recurved posteriorly); (3) habitat (brackish. vs. marine); (4) the dorsal (vs. ventral) position of the contractile vacuole (Kahl 1933).

Vorticella hamata Ehrenberg, 1831 also resembles V. paralima sp. $n$. in terms of its zooid shape and size, habitat and number of silverlines. Nevertheless, the two can be separated by the shape of the macronucleus (C-shaped vs. J-shaped) (Song 1991).

The present form is similar to $V$. striata Dujardin, 1841 in terms of body shape and general appearance in vivo. However, the latter species can be clearly separated from $V$. paralima sp. $\mathrm{n}$ by its shorter zooid in vivo (22-40 $\mu \mathrm{m}$ vs. 35-50 $\mu \mathrm{m}), \mathrm{C}$-shaped (vs. J-shaped) macronucleus, and the number of silverlines between the aboral trochal band and the scopula (5-7 vs. 7-13) (Song 1991).

Living cells of V. utriculus Stokes, 1885 and V. aequilata Kahl, 1935 also bear some resemblance to $V$. paralima sp. $\mathrm{n}$. in terms of their zooid size and shape and numbers of silverlines. However, $V$. utriculus can be distinguished from V. paralima sp. n. by its C-shaped (vs. J-shaped) macronucleus and indistinct (vs. distinct) pellicular striations (Song 1991; Stokes 1885). Vorticella aequilata can be distinguished from V. paralima sp. n. by its C-shaped (vs. J-shaped) macronucleus (Kahl 1935).

This article is protected by copyright. All rights reserved. 


\section{Phylogenetic positions of four Vorticella species within the Vorticellidae}

In the past decade, several studies have suggested that the family Vorticellidae is a nonmonophyletic assemblage of morphologically diverse groups (Miao et al. 2004; Sun et al. 2012, 2013). Among the genera of Vorticellidae, Vorticella Linnaeus, 1767, Pseudovorticella Foissner and Schiffmann, 1974, and Epicarchesium Jankowski, 1985 were reported to be nonmonophyletic (Sun et al. 2016).

In this study, Vorticella species are distributed among two clades: the majority cluster with Pseudovorticella species in the family Vorticellidae whereas the remainder, including V. microstoma, $V$. infusionum, V. mayeri, V. sphaeroidalis sp. n. and Vorticellides species, group with the Astylozoidae, the sister group of the Vorticellidae. The topology of our tree is consistent with previous studies (Ji et al. 2015; Li et al. 2015; Sun et al. 2012, 2013). .

Among the new species, V. paralima sp. n. groups with Pseudovorticella punctata first with maximal support and both cluster with two Pseudovorticella species with a strongly support. This indicates a very close phylogenetic relationship of $V$. paralima sp. n. with these three Pseudovorticella species. However, they can be clearly differentiated by the zooid shape and silverline system (Ji et al. 2003, 2004, 2006). Vorticella parachiangi sp. n. and V. scapiformis sp. n. cluster together with maximal support to form a group that is sister to the subclade of Pseudovorticella species and V. paralima sp. n.

Vorticella sphaeroidalis sp. n. clusters with Vorticellides species to form a strongly supported subclade that is sister to the Astylozoidae. Foissner et al. (2010) transferred a few Vorticella species to the newly established genus Vorticellides Foissner et al., 2010 based on the possession of two epistomial membranes, a small barrel-shaped zooid (usually $<60 \mu \mathrm{m}$ long), and a minute two-rowed P3. Molecular data also supported a close phylogenetic relationship between small, barrel-shaped species, such as $V$. astyliformis and V. microstoma, and certain stalkless peritrichs such as Opisthonecta spp. and Astylozoon enriquesi (Foissner et al. 2010). Thus, it is not surprising that $V$. sphaeroidalis sp. n. clusters with members of Vorticellides and Astylozoidae based on its small zooid (20-30 $\mu \mathrm{m} \times 15-25 \mu \mathrm{m})$, globular shape, and the structure of P3.

\section{TAXONOMIC SUMMARY}

Order Sessilida Kahl, 1933

Family Vorticellidae Ehrenberg, 1838

Genus Vorticella Linnaeus, 1767

\section{Vorticella parachiangi sp. $\mathbf{n}$.}

Diagnosis. Zooid inverted bell-shaped, 50-65 $\mu \mathrm{m} \times 50-65 \mu \mathrm{m}$ in vivo. Macronucleus J-shaped. Single contractile vacuole dorsally located. 21-31 transverse silverlines between peristome and aboral trochal band, 6-11 between aboral trochal band and scopula. P3 two-rowed; row 1 only half the length of row 2, and terminates together with P2; row 2 of P3 extends to proximal end of P1. Type locality and habitat: Mangrove wetland on Techeng Island in Zhanjiang $\left(21^{\circ} 16^{\prime} \mathrm{N} ; 110^{\circ} 44^{\prime} \mathrm{E}\right)$, Guangdong Province, China. Water temperature $25^{\circ} \mathrm{C}$, salinity $25 \%$, pH about 7.

Deposition of slides: A protargol slide with the holotype specimen circled by ink is deposited in the Laboratory of Protozoology, Ocean University of China, Qingdao, China with the registration number SZ-2010-0314-01-3. One paratype slide with silver nitrate-stained specimens is deposited in the Natural History Museum, London, UK, with the registration number NHMUK 2018:3:1.1.

Etymology: The Greek word para (similar, near) indicates that the type population is similar to Vorticella chiangi Sun et al., 2016.

This article is protected by copyright. All rights reserved. 
Gene sequence. The SSU rDNA sequence has been deposited in GenBank with the accession number KY594767.

ZooBank registration: ZooBank registration number of the present work (see Recommendation $8 \mathrm{~A}$ of ICZN 2012): urn:Isid:zoobank.org: act:87851AFC-EB3D-4F02-A909-D78ECF79CAEB

\section{Vorticella scapiformis sp. $\mathrm{n}$.}

Diagnosis: Zooid elongate obconical, 40-50 $\mu \mathrm{m} \times 40-55 \mu \mathrm{m}$ in vivo, with conspicuously everted peristomial lip. Macronucleus J-shaped. Single contractile vacuole ventrally located. 18-25 silverlines between peristome and aboral trochal band, 8-12 between aboral trochal band and scopula. P3 three-rowed; rows 2 and 3 terminate together with $\mathrm{P} 1$; row 1 of $\mathrm{P} 3$ is proximally shortened terminating with $\mathrm{P} 2$ at curvature of $\mathrm{P} 1$.

Type locality and habitat: Sewage outlet on Donghai Island Zhanjiang $\left(21^{\circ} 02^{\prime} \mathrm{N} ; 110^{\circ} 34^{\prime} \mathrm{E}\right)$, Guangdong Province, China. Water temperature $25^{\circ} \mathrm{C}$, salinity $12 \%$, pH about 9 .

Type specimens: A protargol slide with the holotype specimen circled by ink is deposited in the Laboratory of Protozoology, Ocean University of China with the registration number SZ-2010-0321-01-3. One paratype slide with silver nitrate-stained specimens is deposited in the Natural History Museum, London, UK, with the registration number NHMUK 2018.3.1.2.

Etymology: The Latin adjective scapiform $\cdot i s,-i s,-e([\mathrm{~m}, \mathrm{f}, \mathrm{n}]$; bacilliform) refers to the bacilliform body shape.

Gene sequence. The SSU rDNA sequence has been deposited in GenBank with the accession number KY594768.

ZooBank registration: ZooBank registration number of the present work (see Recommendation $8 \mathrm{~A}$ of ICZN 2012): urn:Isid:zoobank.org: act:06390D5C-670F-4899-87FC-A9D6E05D23A8

\section{Vorticella sphaeroidalis sp. $\mathbf{n}$.}

Diagnosis: Zooid globular, 20-30 $\mu \mathrm{m} \times 15-25 \mu \mathrm{m}$ in vivo, not constricted below peristome. Macronucleus C-shaped. Single contractile vacuole ventrally located. 16-18 transverse silverlines between peristome and aboral trochal band, two between aboral trochal band and scopula.

Type locality and habitat: A small ditch near the coast of Shantou $\left(23^{\circ} 38^{\prime} \mathrm{N} ; 116^{\circ} 68^{\prime} \mathrm{E}\right)$, Guangdong Province, China. Water temperature $23{ }^{\circ} \mathrm{C}$, salinity $5 \%$, pH about 7 .

Type specimens: A protargol slide with the holotype specimen circled by ink is deposited in the Laboratory of Protozoology, Ocean University of China, Qingdao, China with the registration number SZ-2011-0505-01-2. One paratype slide with silver nitrate-stained specimens is deposited in the Natural History Museum, London, UK, with the registration number NHMUK 2018.3.1.3.

Etymology: The Latin adjective sphaeroidalis refers to the globular zooid shape.

Gene sequence. The SSU rDNA sequence has been deposited in GenBank with the accession number KY594766.

ZooBank registration: ZooBank registration number of the present work (see Recommendation $8 \mathrm{~A}$ of ICZN 2012): urn:Isid:zoobank.org: act:F91AC656-E89C-4309-9FB8-5F9BE331F530

\section{Vorticella paralima sp. $\mathbf{n}$.}

Diagnosis: Zooid inverted bell-shaped, 35-50 $\mu \mathrm{m} \times 20-30 \mu \mathrm{m}$ in vivo. Width of peristomial lip about equal to maximum body width. Macronucleus J-shaped or vermiform. Single contractile vacuole dorsally located. 26-35 silverlines between peristome and aboral trochal band, 7-13 between aboral

This article is protected by copyright. All rights reserved. 
trochal band and scopula. Rows 1 and 2 of P3 are half the length of row 3; P2 and P3 terminate at curvature of P1.

Type locality and habitat: Mangrove wetland at Gaoqiao town, Zhanjiang $\left(21^{\circ} 53^{\prime} \mathrm{N} ; 110^{\circ} 28^{\prime} \mathrm{E}\right)$, Guangdong Province, China. Water temperature $23^{\circ} \mathrm{C}$, salinity $23 \%$, pH 7.8.

Type specimens: A protargol slide with the holotype specimen circled by ink is deposited in the Laboratory of Protozoology, Ocean University of China, Qingdao, China with the registration number SZ-2009-1011-01-2; One paratype slide with silver nitrate-stained specimens is deposited in the Natural History Museum, London, UK, with the registration number NHMUK 2018.3.1.4.

Etymology: Composite of the Greek word para.(similar, near) and the specific epithet lima indicating that the type population is similar to Vorticella lima Kahl, 1933.

Gene sequence. The SSU rDNA sequence has been deposited in GenBank with the accession number KY594765.

ZooBank registration: ZooBank registration number of the present work (see Recommendation $8 \mathrm{~A}$ of ICZN 2012): urn:Isid:zoobank.org: act:6E42E1AE-8F12-4E53-9920-0C7ACD25BEOD

\section{ACKNOWLEDGMENTS}

This study was supported by the "National Natural Science Foundation of China" (project numbers: $41576148,41476128,31772413,31430077)$. We acknowledge the helpful suggestions of Weibo Song (OUC, China), the late John C. Clamp (NCCU, USA), the associate editor, anonymous reviewers for the improving of this manuscript.

\section{LITERATURE CITED}

Ehrenberg, C. G. 1838. Die Infusionsthierchen als vollkommene Organismen. Ein Blick in das tiefere organische Leben der Natur. L. Voss, Leipzig: i-xviii+(4), 1-612.

Foissner, W., Blake, N., Wolf, K., Breiner, H. W. \& Stoeck, T. 2010. Morphological and molecular characterization of some peritrichs from tank bromeliads including two new genera Orborhabdostyla and Vorticellides. Acta Protozool., 48:291-319.

Gao, F., Warren, A., Zhang, Q., Gong, J., Miao, M., Sun, P., Xu, D., Huang, J., Yi, Z. \& Song, W. 2016. The all-data-based evolutionary hypothesis of ciliated protists with a revised classification of the phylum Ciliophora (Eukaryota, Alveolata). Sci. Rep., 6, 24874.

Guindon, S., Lethiec, F., Duroux, P. \& Gascuel, O. 2005. PHYML Online-a web server for fast maximum likelihood-based phylogenetic inference. Nucl. Acids Res., 33 (Web Server):W557-W559.

Hall, T. A. 1999. BioEdit: a user-friendly biological sequence alignment editor and analysis program for Windows 95/98/NT. Nucl. Acids Symp. Ser., 41:95-98.

ICZN (The International Commission on Zoological Nomenclature), 2012. Amendment of

Articles 8, 9, 10, 21 and 78 of the International Code of Zoological Nomenclature to expand and refine methods of publication. Bull. Zool. Nom. 69:161-169.

Itabashi, T., Mikami, K., Fang, J. \& Asai, H. 2002. Phylogenetic relationships between Vorticella convallaria and other species inferred from small subunit rRNA gene sequences. Zool. Scr., 19:931-937.

This article is protected by copyright. All rights reserved. 
Jankowski, W. 1976. A revision of the order Sessilida (Peritricha). In: Dumka, N. (Ed.), Materials of the II All Union Conference of Protozoologists. Part I. General Protozoology, pp. 168-170 (in Russian).

Ji, D., Kim, J. H., Shazib, S. U., Sun, P., Li, L. \& Shin, M. K. 2015. Two new species of Zoothamnium (Ciliophora, Peritrichia) from Korea, with new observations of Z. parahentscheli Sun et al., 2009. J. Eukaryot. Microbiol., 62:505-518.

Ji, D., Song, W. \& Al-Rasheid, K. A. S. 2003. Description of a marine peritrichous ciliate, Pseudovorticella sinensis n. sp. (Ciliophora, Peritrichia) from China. J. Eukaryot. Microbiol., 50: 360-365.

Ji, D., Song, W. \& Clamp, J. 2006. Pseudovorticella zhengae n. sp., P. difficilis (Kahl, 1933) Jankowski, 1976, and P. punctata (Dons, 1918) Warren, 1987, three marine peritrichous ciliates from north China. Eur. J. Protistol., 42:269-279.

Ji, D., Song, W. \& Warren, A. 2004. Pseudovorticella paracratera $\mathrm{n}$. sp., a new marine peritrich ciliate (Ciliophora: Peritrichida) from north China. Hydrobiol., 515: 49-57.

Kahl, A. 1933. Ciliata libera et ectocommensalia. In: Grimpe, G. \& Wagler, E. (ed.), Die Tierwelt der Nord- und Ostsee Akademische Verlag. Leipzig., 23:29-146.

Kahl, A. 1935. Urtiere oder Protozoa I: Wimpertiere oder Ciliata (Infusoria). 4. Peritricha und Chonotricha. Tierwelt. Dtl., 30: 651-886.

Li, L., Ma, H. \& Al-Rasheid, K. A. S. 2015. Monophyly or polyphyly? Possible conflict between morphological and molecular interpretations of the well-known genus Zoothamnium (Ciliophora, Peritrichia). Chin. J. Oceanol. Limnol., 33:490-499.

Lynn, D. H. 2008. The Ciliated Protozoa: Characterization, Classification, and Guide to the Literature 3rd edn. Springer, Dordrecht, $605 \mathrm{p}$.

Medlin, L., Elwood, H. J., Stickel, S. \& Sogin, M. L. 1988. The characterization of enzymatically amplified eukaryotic 16S-like rRNA-coding regions. Gene, 71:491-499.

Miao, W., Fen, W. S., Yu, Y. H., Zhang, X. Y. \& Shen, Y. F. 2004. Phylogenetic relationships of the subclass Peritrichia (Oligohymenophorea, Ciliophora) inferred from small subunit rRNA gene sequences. J. Eukaryot. Microbiol., 51:180-186.

Noland, L. E. \& Finley, H. E. 1931. Studies on the taxonomy of the genus Vorticella. Trans. Am. Microsoc. Soc., 50:80-123.

Nylander, J. A. A. 2004. MrModeltest version 2. Distributed by the author. Uppsala, Sweden: Department of Systematic Zoology, Evolutionary Biology Centre, Uppsala University.

Ronquist, F. \& Huelsenbeck, J. P. 2003. MrBayes 3: Bayesian phylogenetic inference under mixed models. Bioinformatics, 19:1572-1574.

Shen, Z., Ji, D. D., Yi, Z. Z., Al-Rasheid, K. A. S. \& Lin, X. F. 2017. Morphology and phylogenetic placement of three new Zoothamnium species (Ciliophora: Peritrichia) from coastal waters of Southern China. J. Eukaryot. Microbiol., DOI: 10.1111/jeu.12358

Sommer, G. 1951. Die peritrichen Ciliaten des Großen Plöner Sees. Arch. Hydrobiol., 44: 349-440.

Song, W. 1991. Contribution to the commensal ciliates on Penaeus orientalis. II. (Ciliophora, Peritrichida). J. Ocean Univ. Qingdao, 21:45-55 (in Chinese with English summary).

Song, W. 1997. A new genus and two new species of marine peritrichous ciliates (Protozoa, Ciliophora, Peritrichida) from Qingdao, China. Ophelia, 47: 203-214.

This article is protected by copyright. All rights reserved. 
Song, W. \& Warren, A. 2000. A redescription of Pseudovorticella patellina (O. F. Müller, 1776) nov. comb., a peritrichous ciliate (Protozoa: Ciliophora: Peritrichida) isolated from mariculture biotopes in north China. Acta Protozool. 39:43-50.

Song, W. \& Wilbert, N. 1995. Benthische Ciliaten des Süßwassers. In: Röttger, R. (ed.), Praktikum der Protozoologie. Gustav Fischer, New York. P. 156-168.

Sun, P., Al-Farraj, A. S., Warren, A. \& Ma, H. G. 2017. Morphology of four new solitary sessile peritrich ciliates from the Yellow Sea, China, with description of an unidentified species of Paravorticella (Ciliophora, Peritrichia). Eur. J. Protistol., 57:73-84.

Sun, P., Clamp, J., Xu D., Huang, B. \& Shin, M. K. 2016. An integrative approach to phylogeny reveals patterns of environmental distribution and novel evolutionary relationships in a major group of ciliates. Sci. Rep., 6:21695.

Sun, P., Clamp, J. C., Xu, D., Huang, B., Shin, M. K. \& Turner, F. 2013. An ITS-based phylogenetic framework for the genus Vorticella: finding the molecular and morphological gaps in a taxonomically difficult group. Proc. R. Soc. B. 280, 20131177.

Sun, P., Clamp, J. C., Xu, D., Kusuoka, Y. \& Miao, W. 2012. Vorticella Linnaeus, 1767 (Ciliophora, Oligohymenophora, Peritrichia) is a grade not a clade: redefinition of Vorticella and the families Vorticellidae and Astylozoidae using molecular characters derived from the gene coding for small subunit ribosomal RNA. Protist, 163:129-142.

Sun, P., Ji, D., Warren, A. \& Song, W. 2009. Solitary sessilid peritrichs. In: Song, W., Warren, A. \& $\mathrm{Hu}, \mathrm{X}$. (ed.), Free-living ciliates in the Bohai and Yellow Seas, China. Science Press, Beijing. p. 217-256.

Sun, P., Song, W., Clamp, J. C. \& Al-Rasheid, K. A. S. 2006. Taxonomic characterization of Vorticella fusca Precht, 1935 and Vorticella parapulchella n. sp., two marine peritrichs (Ciliophora, Oligohymenophorea) from China. J. Eukaryot. Microbiol., 53:348-357.

Sun, P., Warren, A., Al-Farraj, S. A. \& Song, W. 2015. Morphology of three new colonial sessile peritrich ciliates, Pseudepistylis paramphora n. sp., Zoothamnium paranii n. sp. and Z. hartwigi $\mathrm{n}$. sp., with notes on Epicarchesium variabile (Ciliophora, Peritrichia). Eur. J. Protistol., 51:186-195.

Utz, L. R. P., Simão, T. L. L., Safi, L. S. L. \& Eizirik, E. 2010. Expanded phylogenetic representation of genera Opercularia and Epistylis sheds light on the evolution and higher-level taxonomy of peritrich Ciliates (Ciliophora: Peritrichia). J. Eukaryot. Microbiol., 57:415-420.

Warren, A. 1986. A revision of the genus Vorticella (Ciliophora: Peritrichida). Bull. Br. Mus. nat. Hist. (Zool.). 50:1-57.

Wilbert, N. 1975. Eine verbesserte Technik der Protargolimprägnation für Ciliaten. Mikrokosmos, 64:171-179.

\section{Figure legends}

Figure 1 Vorticella parachiangi sp. $\mathrm{n}$. in vivo (A-C) and after silver nitrate (D) and protargol (E, F) staining. A. General view of typical zooid; B. Showing proportion of stalk and zooid; C. Typical zooid. Arows indicate folds on the surface; D. Silverline system. Arrow marks the aboral trochal band; arrowhead indicates pellicular pore; E. Infraciliature and macronucleus; F. Oral ciliature. Arowhead marks the epistomial membrane. $\mathrm{H}$, haplokinety; $\mathrm{G}$, germinal kinety; $\mathrm{Ma}$, macronucleus; $\mathrm{P1}$-3, infundibular polykinety1-3; Po, polykinety. Scale bars: $40 \mu \mathrm{m}$ (A); $200 \mu \mathrm{m}$ (B); $25 \mu \mathrm{m}$ (E).

This article is protected by copyright. All rights reserved. 
Figure 2 Photomicrographs of Vorticella parachiangi sp. n. in vivo (A-F) and after protargol (G-H) and silver nitrate (I) staining. A. Lateral view showing the stalk length relative to the zooid; B. Apical view. Arrows mark margin of peristomial lip; C. Lateral view of zooid showing thickness of peristomial lip (arrow); D. Contractile vacuole (arrow) and food vacuole (arrowhead); E. Zooid at high magnification and with differential interference contrast optics. Arrows indicate pellicular striations; F. Detail of stalk; G. Macronucleus (arrows) and aboral trochal band (arrowhead); H. Oral ciliature. Arrow marks infundibular polykinety 3; I. Lateral view showing silverline system. Scale bars: $135 \mu \mathrm{m}$ (A); $30 \mu \mathrm{m}$ (B); $15 \mu \mathrm{m}(\mathrm{F}) ; 15 \mu \mathrm{m}(\mathrm{G})$.

Figure 3 Morphology and infraciliature of Vorticella scapiformis sp. $n$. in vivo (A-D) and after protargol staining (E, F). A. General lateral view of typical zooid; B. Lateral view showing the proportion of stalk and zooid; C. Showing irregular protuberances on edge of peristomial lip (arrows); D. Details of stalk; E. Showing general infraciliature and macronucleus (arrow); F. Oral ciliature. Arrowhead indicates epistomial membrane. H, haplokinety; G, germinal kinety; P1-3, infundibular polykinety 1-3; Po, polykinety. Scale bars: $40 \mu \mathrm{m}$ (A); $200 \mu \mathrm{m}$ (B); $15 \mu \mathrm{m}$ (E).

Figure 4 Photomicrographs of Vorticella scapiformis sp. $\mathrm{n}$. in vivo (A-F) and after protargol (G-H) and silver nitrate (I) staining. A. Lateral view, showing the proportion of stalk and zooid; B. Showing irregular protuberances on edge of peristomial lip (arrows); C. Showing contractile vacuole (arrow); D. Showing food vacuole (arrow); E. Zooid at high magnification. Arrows show pellicular striations; F. Details of stalk. Arrow indicates thecoplasmic granules in the spasmoneme; G. Arrows show macronucleus; H. Oral ciliature. Arrow indicates infundibular polykinety 3; I. Silverlines. Scale bars: $200 \mu \mathrm{m}(\mathrm{A}) ; 20 \mu \mathrm{m}$ (B, D, G).

Figure 5 Morphology and infraciliature of Vorticella sphaeroidalis sp. $n$. in vivo (A-B), after protargol (C, D) and silver nitrate (E) staining. A. General view of typical zooid; B. Lateral view, showing the proportion of stalk and zooid; C. Oral ciliature. Arrowhead marks epistomial membrane; D. General infraciliature and myoneme system; E. Silverline system. Arrow marks the aboral trochal band. $H$, haplokinety; G, germinal kinety; P1-3, infundibular polykinety 1-3; Po, polykinety. Scale bars: $15 \mu \mathrm{m}$ (A); $40 \mu \mathrm{m}$ (B); $6 \mu \mathrm{m}$ (D).

* In C, the initial (i.e. proximal) position of P3 is shown, but the terminal (i.e. distal) position and the number of kinetosomal rows is indeterminate.

Figure 6 Photomicrographs of Vorticella sphaeroidalis sp. $n$. in vivo (A-E), after protargol (F-G) and silver nitrate (H-I) staining. A. Typical zooid in vivo; B. Showing contractile vacuole (arrow); C. Showing food vacuole (arrowhead) and macronucleus (arrowhead); D. Granules on the surface (arrow); E. Zooid at high magnification. Arrows show pellicular striations; F. Arrow shows myoneme system; G. Showing macronucleus (arrow), infundibular polykinety 3 (arrowhead) and aboral trochal band (double-arrowheads); H. Showing silverline system. Arrow indicates silverline; I. Showing pellicular pores (arrowheads). Scale bars: $15 \mu \mathrm{m}(\mathrm{A}) ; 10 \mu \mathrm{m}(\mathrm{H}, \mathrm{J})$.

Figure 7 Morphology and infraciliature of Vorticella paralima sp. n. in vivo (A-B), after protargol (C-D) and silver nitrate (E) staining. A. General view of typical zooid; B. Showing the proportion of stalk and zooid; C. Showing myoneme system and macronucleus; D. General infraciliature. Arrow

This article is protected by copyright. All rights reserved. 
indicates macronucleus. Arrowhead marks aboral trochal band; E. Showing oral ciliature. Arrowhead marks epistomial membrane. $\mathrm{H}$, haplokinety; G, germinal kinety; P1-3, infundibular polykinety 1-3; Po, polykinety. Scale bars: $30 \mu \mathrm{m}$ (A); $90 \mu \mathrm{m}$ (B); $20 \mu \mathrm{m}$ (E).

Figure 8 Photomicrographs of Vorticella paralima sp. $\mathrm{n}$. in vivo (A-C), after protargol (D-E) and silver nitrate (F-G) staining. A. Lateral view of zooid at low magnification; B. Typical zooid in vivo.

Arrowhead marks contractile vacuole. Arrow indicates depression on surface; C. Showing pellicular striations (arrow); D. Showing macronucleus (arrow) and aboral trochal band (arrowhead); E. Showing oral infraciliature. Arrow indicates infundibular polykinety 3; F. Showing pellicular pores; G. Showing silverlines. Scale bars: $60 \mu \mathrm{m}(\mathrm{A}) ; 20 \mu \mathrm{m}(\mathrm{B}, \mathrm{E}) ; 15 \mu \mathrm{m}(\mathrm{F}, \mathrm{H})$.

Figure 9 Maximum likelihood tree inferred from small subunit rDNA gene sequences indicating phylogenetic positions of Vorticella parachiangi sp. n., V. scapiformis sp. n., V. sphaeroidalis sp. n. and Vorticella paralima sp. $\mathrm{n}$. (bold typeface and arrows). Numbers at the nodes represent support values in the following order: Maximum Likelihood (ML) bootstrap values and Bayesian inference (BI) posterior probabilities. GenBank accession numbers follow each species name. Nodes absent from one of the two phylogenetic analyses are indicated by a hyphen instead of a support value. The scale bar indicates two substitutions per 100 nucleotides.

This article is protected by copyright. All rights reserved. 
Table 1. Characterization of zooid size and silverline system of Vorticella parachiangi sp. n., $V$. scapiformis sp. n., V. sphaeroidalis sp. n. and V. paralima sp. n.

\begin{tabular}{|c|c|c|c|c|c|c|}
\hline Characters $\underline{\text { a }}$ & Species & Min & Max & Mean & SD & $\mathrm{n}$ \\
\hline \multirow{4}{*}{ Zooid length in vivo ${ }^{b}$} & V. parachiangi & 50 & 65 & 55.70 & 4.76 & 10 \\
\hline & V. scapiformis & 40 & 50 & 44.31 & 4.50 & 7 \\
\hline & V. sphaeroidalis & 20 & 30 & 23.33 & 4.08 & 6 \\
\hline & V. paralima & 35 & 50 & 42.50 & 4.63 & 8 \\
\hline \multirow{4}{*}{ Zooid width in vivo ${ }^{b}$} & V. parachiangi & 50 & 65 & 53.00 & 3.50 & 10 \\
\hline & V. scapiformis & 40 & 55 & 44.30 & 6.07 & 7 \\
\hline & V. sphaeroidalis & 15 & 25 & 18.33 & 4.08 & 6 \\
\hline & V. paralima & 20 & 30 & 23.75 & 3.54 & 8 \\
\hline \multirow[t]{4}{*}{ Number of silverlines ${ }^{c}$} & V. parachiangi & 21 & 31 & 25.72 & 2.66 & 22 \\
\hline & V. scapiformis & 18 & 25 & 22.57 & 2.70 & 7 \\
\hline & V. sphaeroidalis & 16 & 18 & 17.50 & 2 & 8 \\
\hline & V. paralima & 26 & 35 & 30.50 & 2.70 & 14 \\
\hline \multirow[t]{4}{*}{ Number of silverlines ${ }^{d}$} & V. parachiangi & 6 & 11 & 7.50 & 1.41 & 22 \\
\hline & V. scapiformis & 8 & 12 & 9.86 & 1.35 & 7 \\
\hline & V. sphaeroidalis & 2 & 2 & 2 & 0 & 8 \\
\hline & V. paralima & 7 & 13 & 10.36 & 1.7 & 14 \\
\hline
\end{tabular}

aData of silverlines based on Chatton-Lwoff silver nitrate-stained specimens.

Min, minimum; Max, maximum; Mean, arithmetic mean; SD, standard deviation; $n$, sample number.

${ }^{\mathrm{b}}$ Measurements in $\mu \mathrm{m}$.

'Number of silverlines between peristome and aboral trochal band.

${ }^{\mathrm{d}}$ Number of silverlines between aboral trochal band and scopula.

This article is protected by copyright. All rights reserved. 

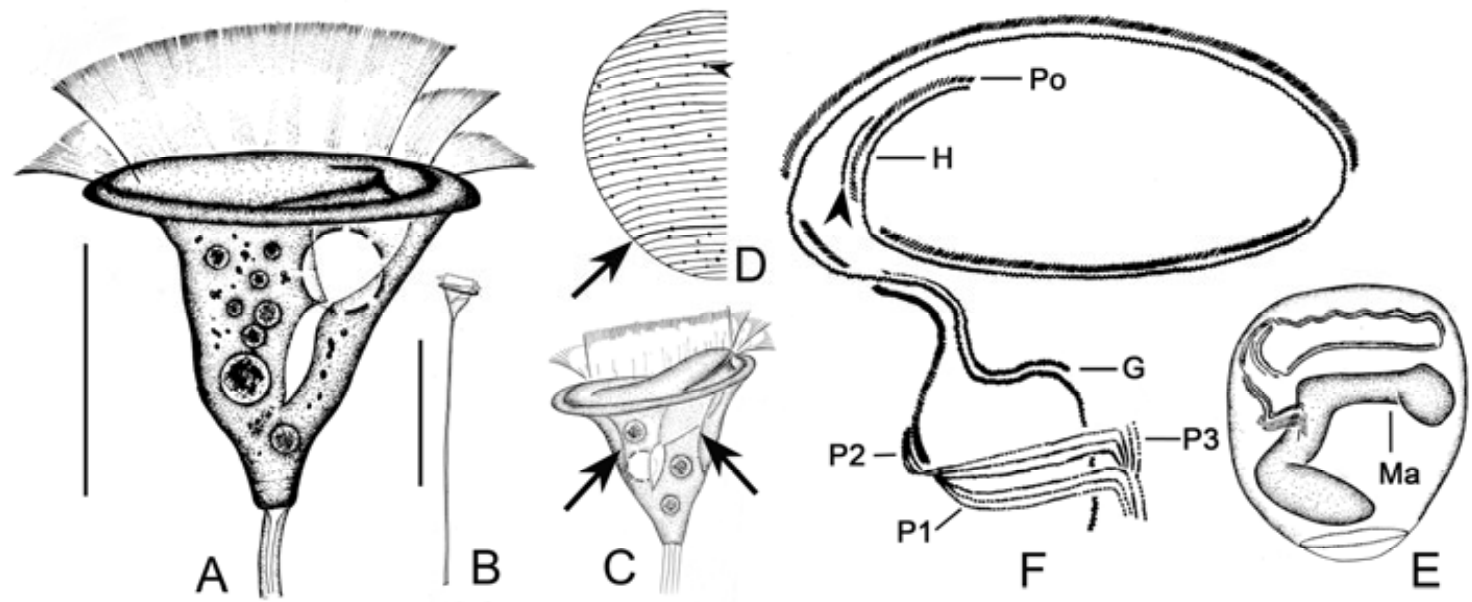

This article is protected by copyright. All rights reserved. 

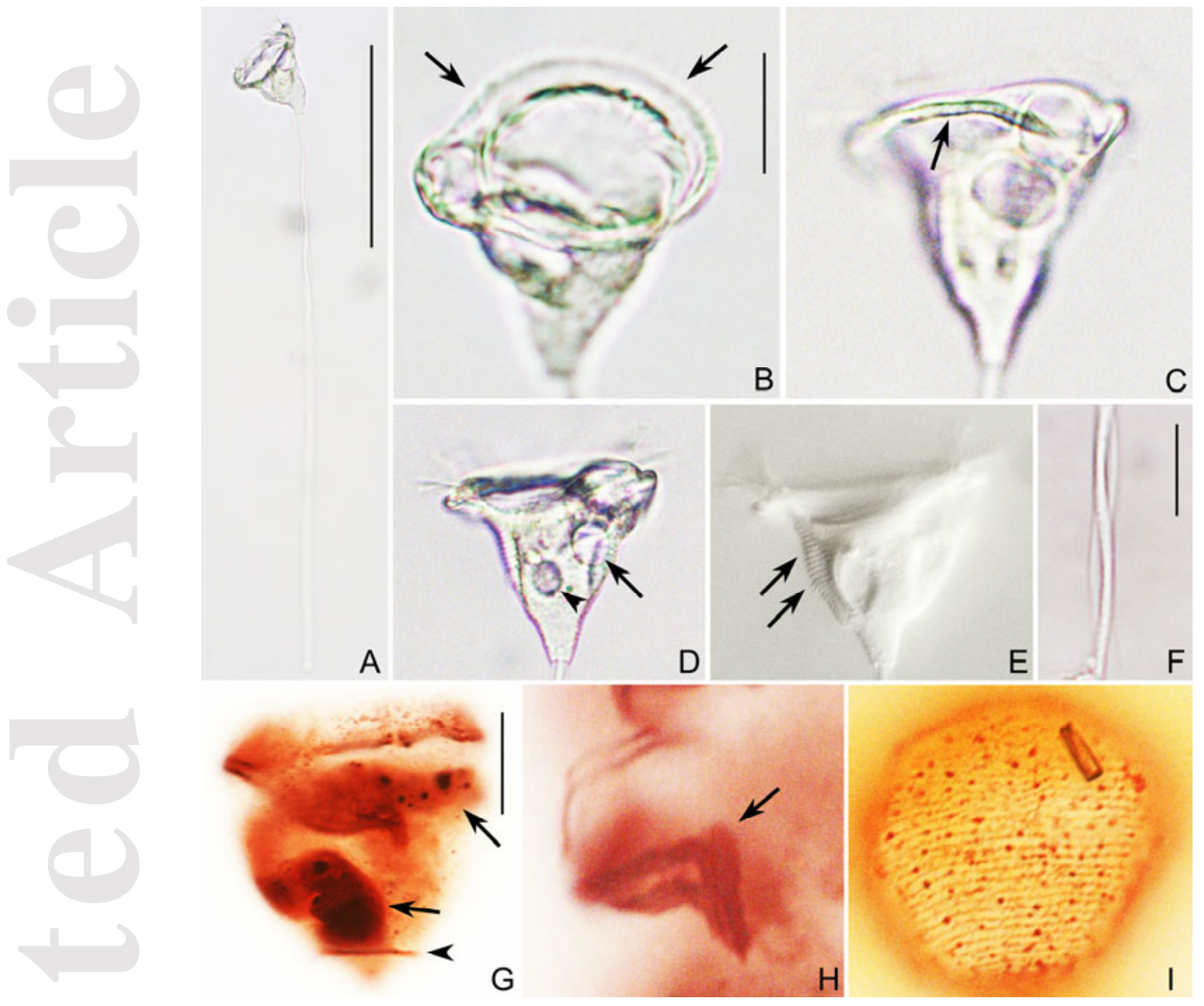

This article is protected by copyright. All rights reserved. 

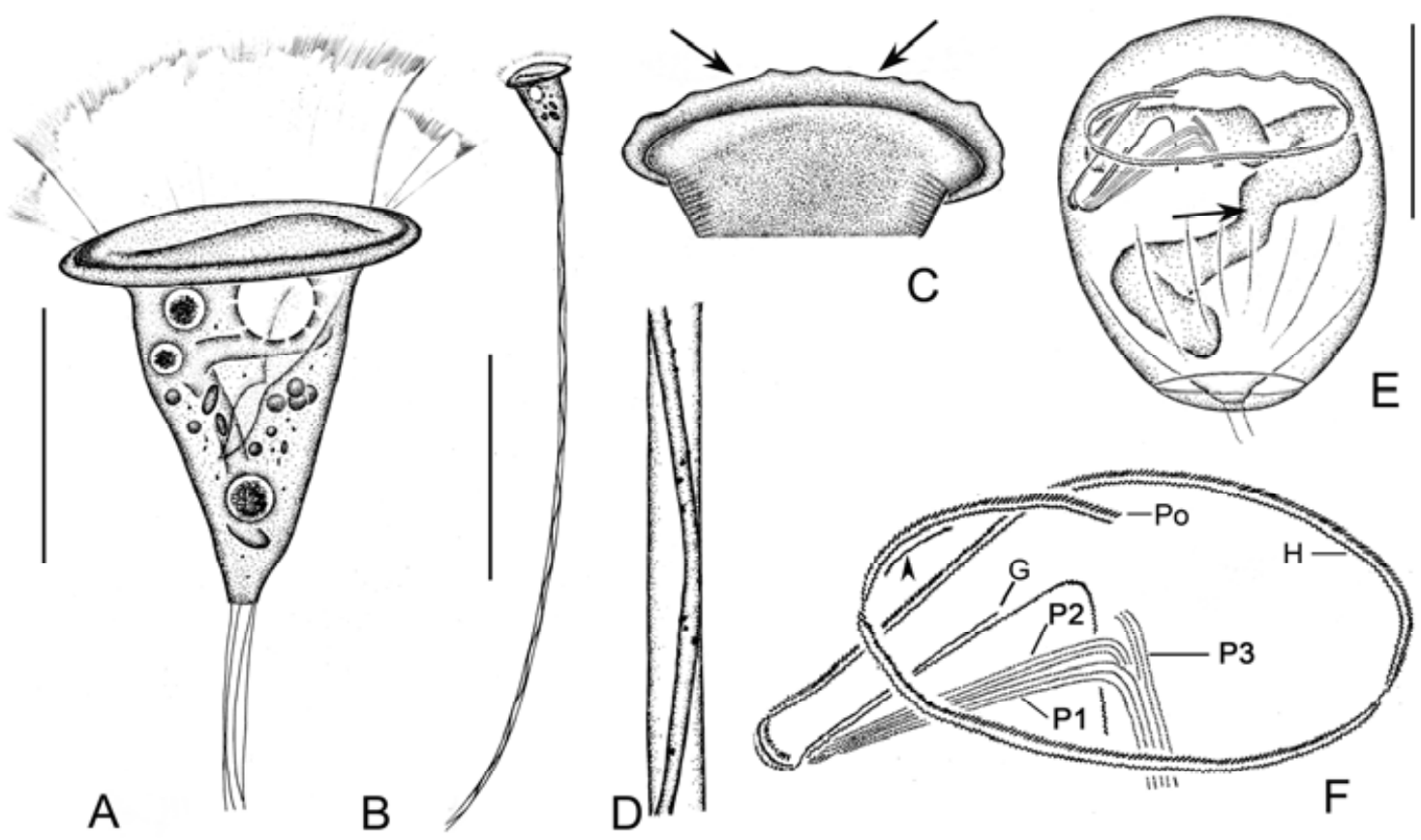

This article is protected by copyright. All rights reserved. 


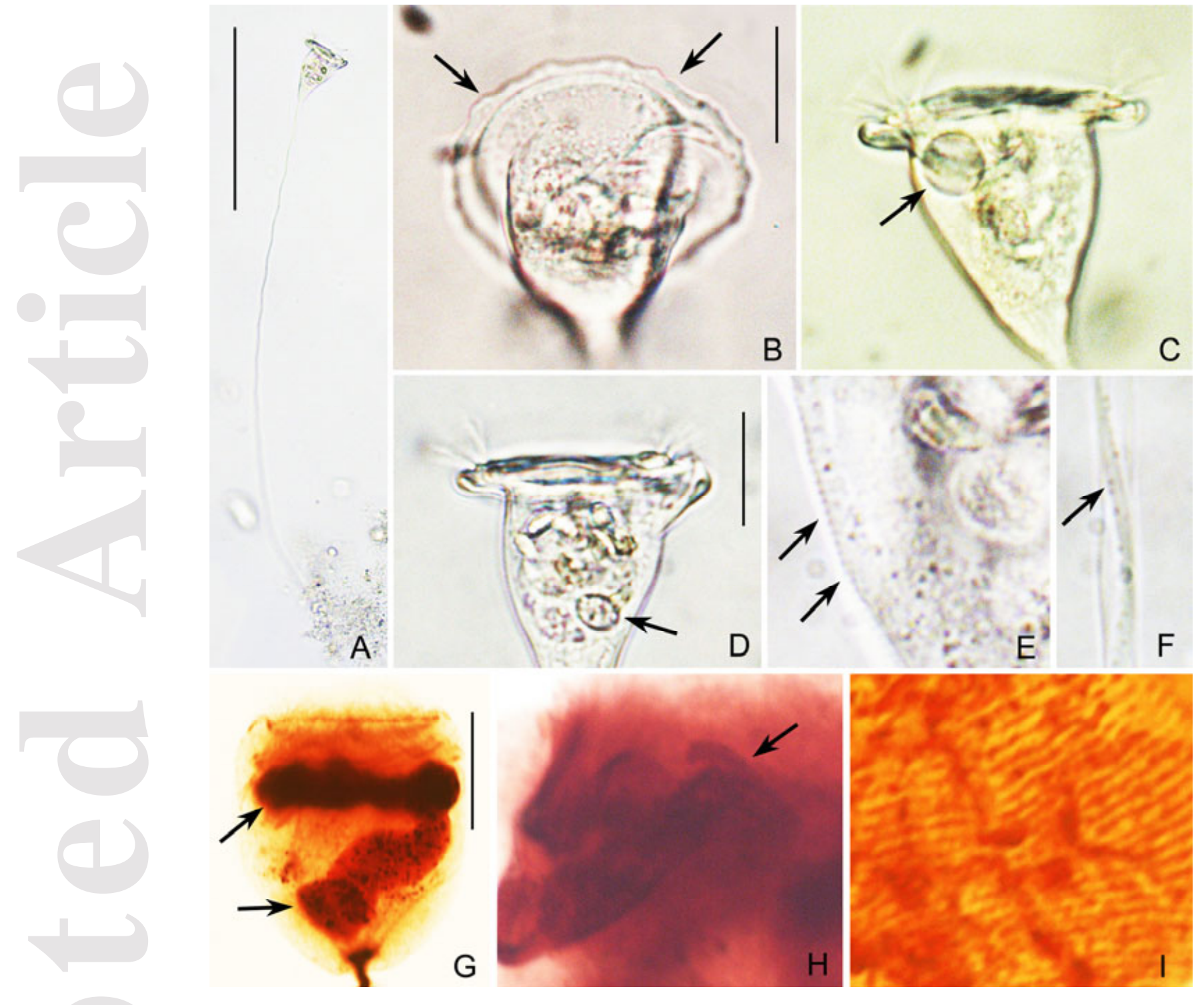

This article is protected by copyright. All rights reserved. 


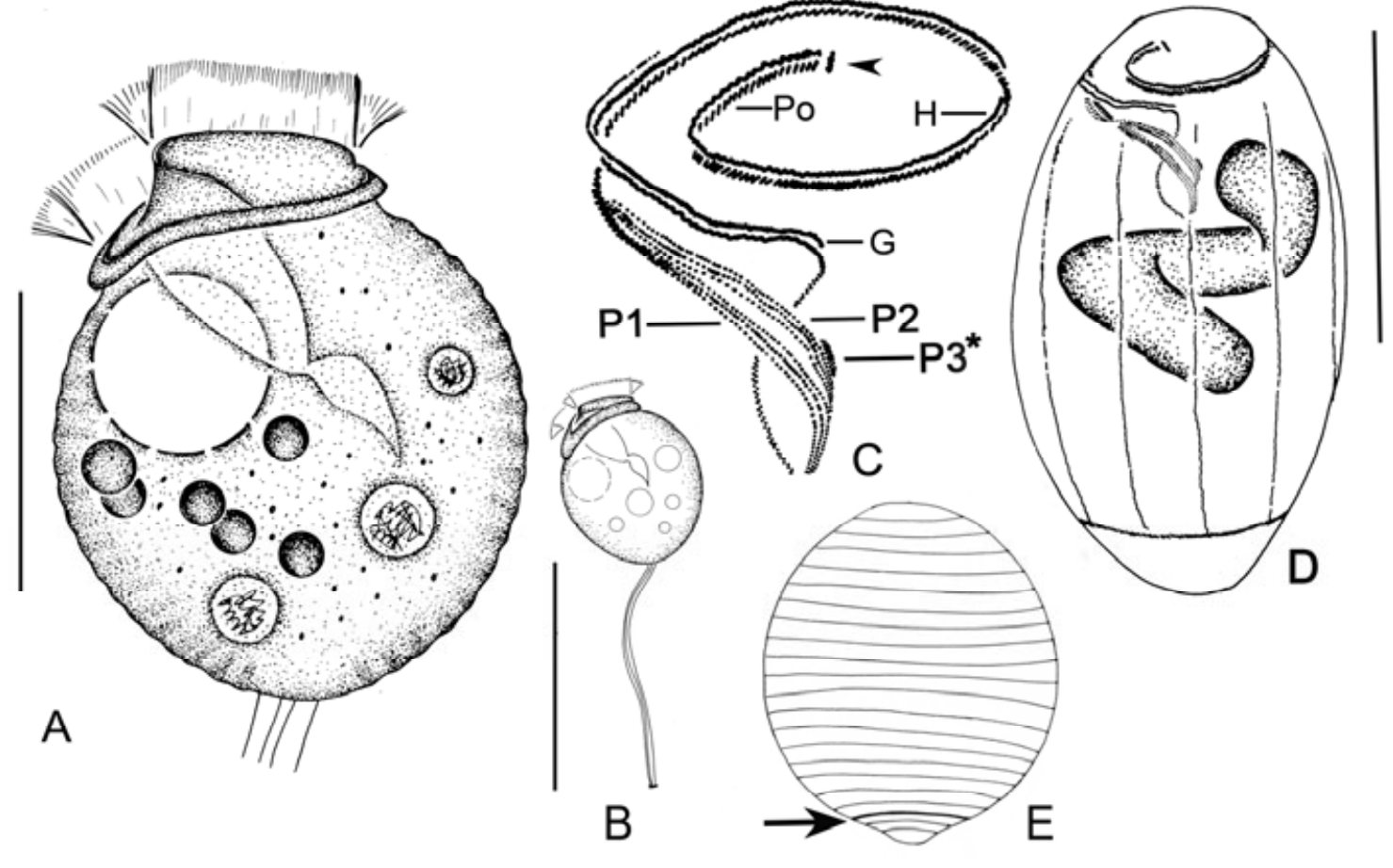

This article is protected by copyright. All rights reserved. 

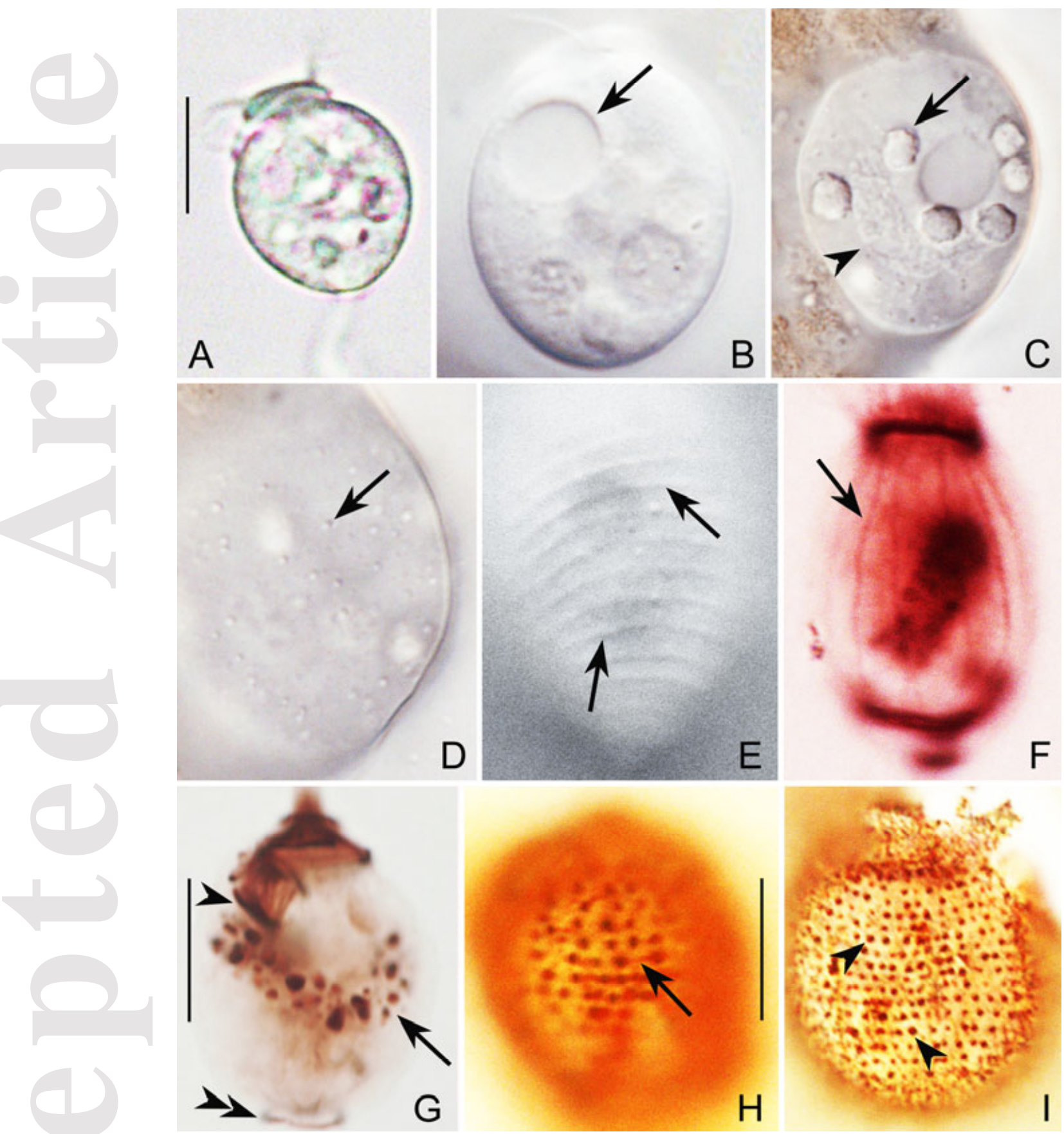

This article is protected by copyright. All rights reserved. 

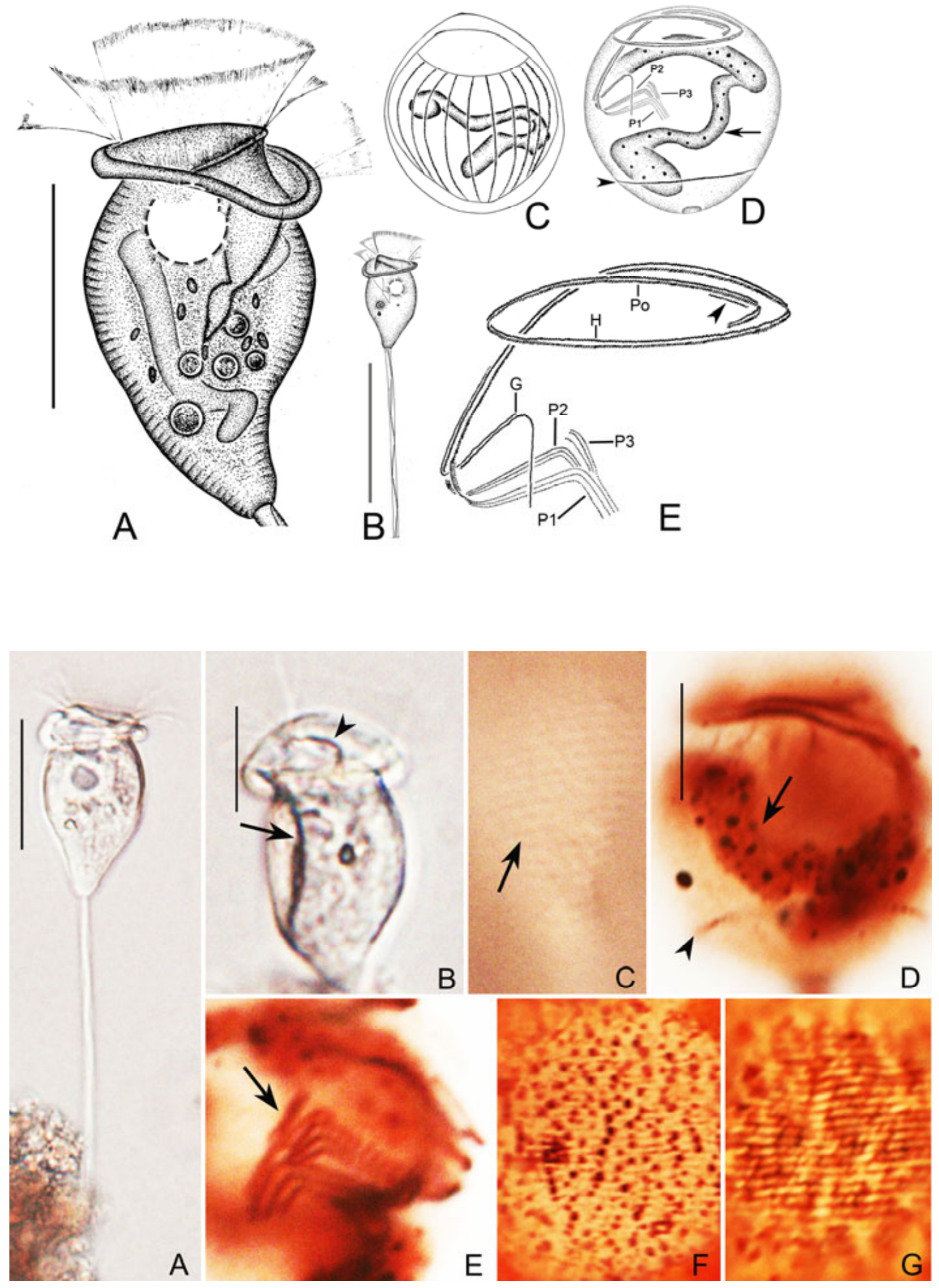

This article is protected by copyright. All rights reserved. 


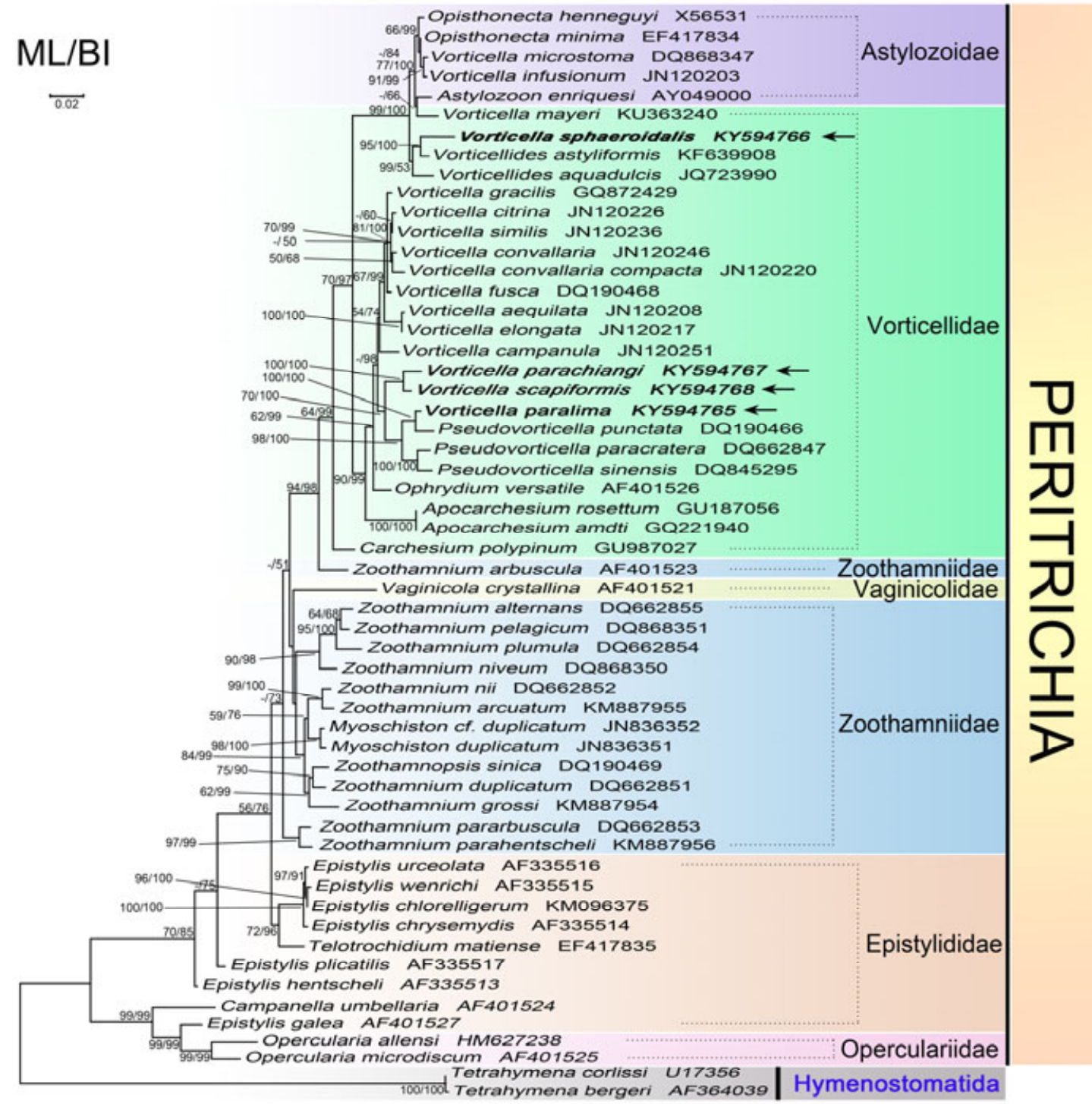

This article is protected by copyright. All rights reserved. 